\title{
AD HOC COMPULSORY ARBITRATION STATUTES: THE NEW DEVICE FOR SETTLING NATIONAL EMERGENCY LABOR DISPUTES
}

The recent labor disputes in the railroad and airline industries once again demonstrated the need for a legal device to avert work stoppages that would cause irreparable damage to the national economy. Although compulsory arbitration is almost universally opposed by both labor and management and had never before been imposed on American industry in peace time, Congress embraced a strictly limited form of this settlement process in enacting Public Laws 88-108 and 90-54. This comment reviews the recent experience under these two ad hoc statutes passed to prevent national rail strikes. The particular problems arising under these statutes, as well as the policy ends served, are analyzed, and provisions to be included in any future ad hoc compulsory arbitration scheme are suggested.

S trikes by employees whose services are essential to the national $S_{\text {welfare have precipitated the criticism that present federal law }}$ provides inadequate protection against the consequences of national emergency labor disputes. On three occasions in the past five years, Congress confronted the problem of work stoppages in industries critical to the national health and safety: first in the 1963 railroad work rules dispute, ${ }^{1}$ then in the airline strike in $1966,{ }^{2}$ and again in 1967 when another railroad labor dispute threatened the essential transportation services of the nation. ${ }^{3}$ Since existing federal labor law leaves disputants ultimately free to strike or lockout, ${ }^{4}$ regardless of the disastrous effect on the public as a whole, Congress has had to decide

\footnotetext{
'See S. Rep. No. 459, 88th Cong., 1st Sess. (1963); H.R. Rep. No. 713, 88th Cong., 1st Sess. (1963).

${ }^{2}$ See S.J. Res. 186, 89th Cong., 2d Sess. (1966); S. Rep. No. 1424, 89th Cong., 2d Sess. (1966); 112 CONG. REC. 18055-099, 18287-323 (1966).

${ }^{3}$ See S. REP. No. 292, 90th Cong., lst Sess. (1967); H.R. REP. No. 353, 90th Cong., Ist Sess. (1967).

4The sections of the Taft-Hartley Act which deal with national emergency disputes set forth a series of detailed procedures, mainly involving delaying actions, which can be invoked to stall a
} 
in each instance whether to enact special legislation to resolve such disputes. Among those legal devices proposed for resolving national emergency labor disputes and for protecting the public interest, none is more an anathema to labor and management than compulsory arbitration. ${ }^{5}$

The notable exception to the general opposition to compulsory arbitration is in the railroad industry, ${ }^{6}$ which by virtue of legislation enacted in 1963 and 1967 has had the only recent experience with this settlement process. The legal effect of Public Laws 88-108 and $90-54^{8}$ extended only to settlement of the particular disputes at hand, but the conflicts involving competing public policies and technical legal construction of the statutes suggest problems that would have to be resolved under a general compulsory arbitration system. More significantly, Public Laws $88-108$ and $90-54$ provide the only framework for testing the new method that Congress has adopted to deal with national emergency labor disputes-compulsory arbitration imposed by temporary ad hoc legislation. In an effort to assess the implications for future legislation, this comment explores the distinctions between compulsory arbitration and common voluntary arbitration in light of the policy concerns behind each, and analyzes the litigation resulting from these two innovative statutes.

\section{The Nature of Compulsory Arbitration}

Compulsory arbitration is a process of settlement of labor disputes whereby the parties are required by law to accept a third

work stoppage in a critical industry. Labor-Management Relations Act (Taft-Hartley Act) $\S \S$ 206-210, 29 U.S.C. \$\$ 176-80 (1964); see Rehmus, Operation of the National Emergency Provisions of LMRA, 62 YALE L.J. 1047 (1953). Similarly, the Railway Labor Act prescribes procedures for altering the terms of employment in the railroad and airlines industries, with provision for mediation and "cooling off" periods in the event of disputes which threaten serious work stoppages. Railway Labor Act §§ 6-10, 45 U.S.C. §§ 156-60 (1964). But under both statutes, the right to resort to self-help in the event of a total breakdown in the settlement machincry is preserved. See Florida E.C. Ry. v. Brotherhood of R.R. Trainmen, 336 F.2d 172, 181 (5th Cir. 1964), cert. denied, 379 U.S. 990 (1965).

s See Railroads v. Operating Brotherhoods, 41 Lab. Arb. 673, 698 (Bd. of Arb. 1964) (dissent of R. McDonald); H.R. REP. No. 353, 90th Cong., Ist Sess. 3 (1967); 112 CoNG. REC. 18063065 (1966) (remarks of Senator Morse); 1966 A BA LABOR Relations SECTION 323-24; Currie, Foreword, 12 LAW \& CONTEMP. PROB. 209, 210 (1947); Cushman, Paradoxes in LaborManagement Relations, 4 LAB. ReL. REP. If 8097 (1967) (statement of NLRB general counsel). See also Nat'l Ass'n Mfrs., Settlement of Labor Disputes and Wage Stabilization, May 2, 1951.

6 See 1966 A BA Labor Relations Section 341-43.

${ }^{7}$ Act of August 28, 1963, Pub. L. No. 88-108, 77 Stat. 132.

'Act of July 17, 1967, Pub. L. No. 90-54, 81 Stat. 122. 
party's resolution of the disputed issues..$^{9}$ As an essential corollary of compulsory arbitration, the ultimate self-help weapons of strike and lockout are outlawed..$^{10}$ Although voluntary arbitration achieves the same result of precluding work stoppages, it differs from compulsory arbitration in that a voluntary arbitration award derives its force from the parties' consent to an arbitration submission agreement, rather than by the authority of an underlying legislative fiat. This distinction emphasizes the mandatory nature of the compulsory arbitration process by clearly identifying the power which removes from the parties their right to strike or lockout. A further difference is that the procedures and rules customarily followed in voluntary arbitration are not necessarily required by compulsory arbitration legislation. For example, whereas a voluntary arbitration panel usually must consider only the evidence presented in making its award, the Special Board established under Public Law 90-54 had power to compromise the parties' interests without regard to the evidence." Keeping these distinctions in mind, the law which has developed around voluntary arbitration may still be highly relevant to an analysis of many legal issues raised by compulsory arbitration statutes.

In considering the practical as well as the legal issues raised by compulsory arbitration legislation, a distinction must be made

\footnotetext{
'See F. Elkouri \& E. El.kouri, How ARbitration Works 12 (1960); Sanders, Types of Labor Disputes and Approaches to Their Settlement, 12 LAW \& CONTEMP. PROB. 211, 216-17 (1947); Williams, The Compulsory Settlement of Contract Negotiation Labor Disputes, 27 TEXAS L. REV. 587, 588 (1949); Should the Federal Government Require Arbitration of Labor Disputes in All Basic American Industries, 26 Cong. Dig. 193, 195 (1947). But cf. Sturges, "Compulsory Arbitration"-What Is It?, 30 FordHAM L. REv. 1 (1961). Although Professor Sturges' analysis of the different settlement processes that have been called compulsory arbitration demonstrates some confusion as to the precise meaning of the term, common usage emphasizes the compulsory nature of this settlement process, as do the commentators cited above. See, e.g., TimE, March 1, 1968, at 35; Washington Post, June 1, 1967, at A18, col. 1; N.Y. Times, Dec. 1, 1966, at 46, col. 1.

For a selected bibliography listing recent publications on the subject of compulsory arbitration see U.S. DeP'T of LABOR, COMPulsory ARBitration: Selected References 1951-66 (February 1966).

${ }^{10}$ See Frey, The Logic of Collective Bargaining and Arbitration, 12 LAW \& ConTEMP. ProB. 264, 272 (1947); Williams, supra note 9, at 588.

"See S. ReP. No. 292, 90th Cong., 1st Sess. 3 (1967); 113 Cong. Rec. 7783 (daily ed. June 7, 1967) (remarks of Senator Morse). Also, unlike the provisions of Public Law 90-54, voluntary arbitration procedures sometimes require that the proponent of an issue carry the burden of proof on that issue, and establish his position by a preponderance of the evidence. See S. REP. No. 292, 90th Cong., lst Sess. 3 (1967); ElKouRI, supra note 9, at 416-19.
} 
between temporary as opposed to permanent laws imposing this settlement process. With respect to the espoused national policy of promoting collective bargaining, ${ }^{12}$ a permanent compulsory arbitration statute would clearly be more objectionable to those critics who believe it would destroy collective bargaining. ${ }^{13}$ On the other hand, some drawbacks of the ad hoc approach can be seen in the uncertainty resulting from the need for new legislation to meet each new crisis, and in the technical problems of drafting statutes to resolve only the particular issues which are in dispute. Once a compulsory arbitration statute is enacted, whether it is permanent or temporary, would be relevant in resolving such issues as the preemptive effect on state laws regulating the same employment problems. ${ }^{14}$

Another distinction useful in analyzing Public Laws 88-108 and 90-54, especially in assessing their value as precedent, is based upon the differences between the two fundamental types of labor-management conflicts: grievance disputes and new contract negotiations. ${ }^{\text {Is }}$ Grievance disputes grow out of disagreements in the interpretation or application of an existing labor contract, ${ }^{16}$ and are commonly resolved by voluntary arbitration, ${ }^{17}$ or, in the airline and railroad industries, by compulsory arbitration under section 3 of the Railway Labor Act. ${ }^{18}$ In grievance arbitration cases, the arbitrator has the basically judicial function of construing the language of the labor

\footnotetext{
${ }^{12}$ See National Labor Relations Act § 1, 29 U.S.C. § 151 (1964). This statute expressly declares encouragement of the practice and procedure of collective bargaining to be the policy of the United States. See id.

${ }^{13}$ See note 28 infra and accompanying text.

${ }^{14}$ See notes 116-26 infra and accompanying text.

is See T. Kheel, The Pros and Cons of Compulsory Arbitration 13-15, Feb. 7, 1961 (study prepared for the New York Chamber of Commerce); Farmer, Compulsory Arbitration-A Management Lawyer's View, 51 VA. L. Rev. 396, $402-04$ (1965); Feller, Compulsory Arbitration-A Union Lawyer's View. 51 VA. L. Rev. 410, $411-12$ (1965); Sanders, supra note 9; Williams, supra note 9, at 589.

${ }^{16}$ See ElKouri, supra note 9, at 82.

${ }^{17} \mathrm{~A}$ recent analysis of practically all collective bargaining agreements covering 1,000 workers or more, exclusive of airline, railroad and government labor contracts, revealed that $94 \%$ of these agreements provided for arbitration of some or all grievance disputes. U.S. BUREAU of labor Statistics, Dep't of Labor, Bull. No. 1425-6, Major Collective Bargaining AGREEMENTS: ARBITRATION PROCEDURES 5 (1966).

1345 U.S.C. § 153 (1964). By the provisions of this statute Congress set up the National Railroad Adjustment Board and gave the Board jurisdiction over grievance disputes in the industry, including the power to render awards which are final and binding upon both parties. The Supreme Court has construed these provisions as outlawing strikes and lockouts over such disputes. See Brotherhood of R.R. Trainmen v. Chicago R. \& Ind. R.R., 353 U.S. 30 (1957).
} 
contract and thereby adjudicating the "rights" of the parties. ${ }^{19}$ While a provision for arbitration of grievances is incorporated in almost all sizeable collective bargaining agreements ${ }^{20}$ and is favored by a strong federal policy, ${ }^{21}$ voluntary arbitration is rarely used to resolve labor disputes over new contract terms; ${ }^{22}$ even though this type of dispute accounts for the most serious collective bargaining failures. ${ }^{23}$ The reasons for the general aversion to arbitration of new contract disputes are exposed in the numerous policy arguments advanced in opposition to compulsory arbitration.

\section{The Policy Pros and Cons of Compulsory Arbitration}

In contract negotiation disputes, management and labor oppose arbitration on the ground that it segregates decision-making power from ultimate responsibility on issues that are crucial to their fundamental interests. ${ }^{24}$ The great importance of the issues usually involved in contract negotiations is the core of this objection. Whereas a grievance dispute may concern the interests of a single employee, disputes over new contract terms often involve management's fear of a profit squeeze resulting from increased labor costs, or the union's fear of a loss of membership due to elimination of featherbedding

\footnotetext{
19 The terminology of "rights" disputes as opposed to "interests" disputes, which involve negotiations of new labor contracts, was imported from the Scandinavian countries and applied to American labor law. See Spielmans, Labor Disputes on Rights and on Interests, 29 AM. ECON. REV. 299 (1939). Essentially, the "rights-interests" analysis classifies labor disputes along the same lines as the "grievance-contract negotiation" analysis utilized in this comment.

${ }^{20}$ See note 17 supra.

"See United Steelworkers v. IVarrior \& Gulf Nav. Co., 363 U.S. 574 (1960); LaborManagement Relations Act (Taft-Hartley Act) $\$ 203$ (d), 29 U.S.C. $\S 173$ (d) (1964).

${ }^{22}$ See T. Kheel, supra note 15, at 13; Frey, supra note 10, at 277; Jones, Compulsion and the Consensual in Labor Arbitration, 51 VA. L. REv. 369, 387 (1965). A recent Department of Labor study found that less than $2 \%$ of major colleetive bargaining agreements provide for arbitration of new contract terms. See U.S. BuREaU of Labor Statistics, DEP'T of Labor, Bull. No. 1425-6, Major Collective Bargaining Agreements: Arbitration Procedures 95 (1966).

${ }^{23}$ See U.S. Bureau of Labor Statistics, Dep't of Labor, Bull. No. 1460, Analysis of Work Stoppages 1964, at 1 (1964); U.S. BuREau of Labor Statistics, Dep't of Labor, Bull. No. 1420, ANalysis of WORK StOpPages 1963, at 1 (1963); U.S. BuREAu OF Labor Statistics, Dep't of Labor, Bull. No. 1381, ANalysis of Work Stoppages 1962, at 1 (1962); U.S. Bureau of Labor Statistics, DeP'T of Labor, Bull. No. 1339, ANalysis of WORK STOPPAGES 1961, at 1 (1961).

"See Farmer, supra note 15, at 399; Frey, supra note 10, at 274; Hildebrand, The Resolution of Impasses, in National Academy of ARbitrators: The Arbitrator, The NLRB, AND THE COURTS 287, 291 (1967); Jones, supra note 22, at 387-88.
} 
practices..$^{25}$ When parties bargain to impasse and refuse to submit their dispute to arbitration, the party rejecting arbitration probably considers his self-interests so affected that he is unwilling to risk a compromise. Based on these considerations, vehement opposition to compulsory arbitration is to be expected. ${ }^{26}$ But at the same time, from the standpoint of protecting the public interest and continuing the operation of essential industries, some provision for mandatory settlement, such as compulsory arbitration, is necessary in exactly those instances where the parties refuse to compromise.

Another policy objection raised against compulsory arbitration of new contracts involves the lack of standards to control the arbitrator's ruling on contested contract terms. In resolving the issues in a contract negotiation dispute, the arbitrator is not constrained by the terms of an existing labor contract, and as a result-unlike the grievance arbitration process-a reasonable interpretation of contract language does not delimit the arbitrator's discretionary power. ${ }^{27}$ Consequently, the uItimate effect of an adverse decision by the third party cannot be predicted or measured, and this uncertainty generates increased resistance from both labor and management. However, since limitations on the authority of the arbitrator and decisional standards can be prescribed by compulsory arbitration statutes, the substance of this policy argument is that the rules governing the arbitrator's discretion are dictated by the legislature rather than by the disputants who bear the final consequences of the settlement terms. In this form, the argument simply reiterates the basic objection to compulsory arbitration's separation of decision-making from ultimate responsibility.

Critics of compulsory arbitration also charge that this settlement process has a chilling effect on collective bargaining because the parties are inclined to make extreme demands and to refuse compromise on the assumption that the arbitrator will "split the

\footnotetext{
${ }^{25}$ The 1963 railroad work rules dispute, which led to virtual elimination of an entire craft and its union, demonstrated the critical importance of featherbedding issues. See Hearings on the Administration of Public Law 88-108 Before the Senate Comm. on Commerce, 89th Cong., 2d Sess., ser. 89-56, pt. 2, at 1004-062 (1966) (statement of H.E. Gilbert, President, Brotherhood of Locomotive Firemen and Enginemen); Levinson, The Locomotive Firemen's Dispute, 17 LAB. L.J. 671 (1966).

${ }^{26}$ See T. Kheel, supra note 15, at 13; Farmer, supra note 15, at 403-04; Feller, supra note 15, at $412-15$.

${ }^{27}$ See 1966 ABA LABOR Relations Section 323-24; T. Kheel, supra note 15, at 13-14; Farmer, supra note 15, at 403; Feller, supra note 15, at 412; Frey, supra note 10, at 273.
} 
difference" when he resolves the dispute..$^{28}$ Even if this prediction of union-management behavior is accurate, ${ }^{29}$ the argument is valid only if the disputants know that compulsory arbitration will resolve all impasses. Since the ad hoc approach to settling labor disputes leaves the disputants uncertain as to which settlement process will be adopted, if Congress is to act at all, this objection seems inapplicable to ad hoc compulsory arbitration. Indeed, Congress could fail to act, as in the airline strike situation, ${ }^{30}$ or some alternative such as seizure of the industry could be adopted. ${ }^{31}$

Finally, enactment of a compulsory arbitration statute is opposed on the direct grounds that it will not accomplish its legislative purpose of preventing work stoppages. In support of this conclusion, management and labor argue that a compulsory arbitration statute is unenforceable in practice, and that this settlement process actually causes further disputes by requiring employees to work against their will. ${ }^{32}$ On the issue of enforceability, the problems presented by a

"See T. Kheel, supra note 15, at 18-20; Hildebrand, supra note 24, at 291; Should the Federal Government Require Arbitration of Labor Disputes in All Basic American Industries, 26 CoNG. DiG. 193, 203 (1947); The IVall Street Journal, Feb. 26, 1968, at 16, col. I.

${ }^{29}$ Representative Herlong of Florida, in advocating permanent compulsory arbitration for the transportation industry, argued that the inducement to bargain and compromise under a compulsory arbitration system actually should be greater since the parties would prefer to settle the dispute themselves rather than submit it to the uncertainties of an arbitrator. Herlong, Transportation Strikes: A Proposal for Corrective Legislation, 36 FORDHAM L. REv. 175, 18587 (1967).

A related argument is that by precluding a work stoppage as the final bargaining weapon, compulsory arbitration removes the real motivating force behind collective bargaining. See, e.g., 1966 ABA LABOR Relations Section 324; T. Kheel, supra note 15, at 19-20; Farmer, supra note 15, at 399-400. But like all criticisms of compulsory arbitration based on its predicted undermining of colleetive bargaining, this objection presupposes that the collective bargaining process is an end in itself superior to that served by any compulsory arbitration statute. In the modern industrial economy, however, with its high level of interdependence and concomitant vulnerability to disruption, this assumption may not always be valid.

${ }^{30}$ The Senate passed S.J. Res. 186, 89th Cong., 2d Sess. (1966), which would have broken the airline strike for 180 days, but the measure failed to get through the House.

"Seizure was actively debated and had the support of several powerful legislators during the 1967 railroad labor dispute. During debate of the bill which eventually became Public Law 90 54, Senator Edward Kennedy of Massachusetts proposed an amendment providing for seizure, but was defeated. See 113 CoNG. REc. 7801-09 (daily ed. June 7, 1967). The "arsenal of weapons" approach to emergency disputes, whereby the President has a choice of several legal devices to end a work stoppage, including compulsory arbitration and seizure, also has some support. See H.R. 5683, 90th Cong., Ist Sess. (1967); 113 CoNG. REC. 7201-202 (daily ed. June 14, 1967) (remarks of Representative Pickle). For an explanation of the "arsenal of weapons" approach see Cox, The Uses and Abuses of Union Power, 35 Notre Dame LAW. 624 (1960).

${ }^{32}$ See T. Kheel, supra note 15, at 20-22; Frey, supra note 10, at 274-75; Should the Federal 
compulsory arbitration law are indistinguishable from those inherent in any non-voluntary settlement process, or in fact, from any situation where employees are engaged in an illegal strike. Although the conclusion of unenforceability is questionable, this argument correctly emphasizes that the efficacy of a compulsory arbitration law may ultimately depend upon the strike-breaking powers of the courts.

Standing in opposition to all of the foregoing arguments is the sole policy justification for imposing compulsory arbitration-protection of the national welfare against the consequences of a cessation of essential services. When it is reasonably estimated that a one-month work stoppage in an industry would reduce the gross national product by 13 percent and raise the unemployment level to 15 percent, ${ }^{33}$ the self-interests of the unions and employers involved in the dispute pale in comparison. Compulsory arbitration is offered by its proponents as an alternative to the economic warfare which must be accepted if collective bargaining is to remain inviolate.

ln view of the intense opposition to compulsory arbitration, it is not surprising that American experience with this settlement process has been restricted to special circumstances from which it is difficult to generalize. In fact, until 1963 the only American experience with compulsory settlement of labor disputes was during wartime, ${ }^{34}$ and

Government Require Arbitration of Labor Disputes in All Basic American Industries, 26 Cong. Dig. 193, 207 (1947); The Wall Street Journal, Feb. 26, 1968, at 16, col. 1.

${ }^{33}$ See Message from the President of the United States Relative to Rallroad-Labor Disputes, H.R. Doc. No. 142, 88th Cong., 1st Sess. (1963). President Kennedy described graphically the disasterous repercussions that a national rail strike could be expected to generate in such an interdependent economy as the United States. The Council of Economic Advisers estimated that "by the 30th day of a general rail strike, some 6 million nonrailroad workers would have been laid off in addition to the 200,000 members of the striking brotherhoods and 500,000 other railroad employees-that unemployment would reach the 15 percent mark for the first time since 1940-and that the decline in or rate of GNP would be nearly four times as great as the decline which occurred in this nation's worst postwar recession." Id. at 3 .

The forecasted consequences of a national rail strike in 1967 were equally as gloomy. See H.R. REP. No. 353, 90th Cong., Ist Sess. 9 (1967). "A one month strikc would reduce the gross national product by 13 percent." Id. The pressures generated by the Vietnam conflict made such a strike even more potentially damaging.

${ }^{3}$ Although in World War 1 the National War Labor Board had no statutory authority to compel acceptance of its decisions on the merits of contract negotiation disputes, the President through his cmergency seizure powers was able to assure implementation of the Board's "suggestions" on the terms and conditions of employment in any crucial industry. For example, when the recalcitrant management at Smith \& Wesson, an arms manufacturer, refused to abide by the Board's suggested contract terms to end a labor dispute, President Wilson commandeered 
under some limited state statutes. ${ }^{35}$ Then, beginning with the work rules dispute in $1963,{ }^{36}$ Congress embraced a new method of using

the plant and instituted the Board's terms. For an analysis of the activity of the World War 1 War Labor Board see Gregg, The National War Labor Board, 33 HaRv. L. Rev. 39 (1919).

The World War II experience with compulsory arbitration was much more extensive, since the War Labor Disputes Act, 57 Stat. 163 (1943), and the Stabilization Act of 1942, 56 Stat. 765 (1942), granted the President power to control wages and hours, to seize struck plants, and to institute such changes in working conditions as the War Labor Board might have recommended. Since it was a criminal offense to strike a seized plant, the union strike powers were nullified. Under the auspices of this War Labor Board, all labor disputes of national consequence were subject to compulsory settlement on terms dictated by a third party. For commentary on the experience under this dispute settlement process see C. GREGORY, LABOR AND THE LAW 387 (1946); Jaffe, Post-War Labor Relations: The Contributions of the War Labor Board, 29 lowA L. Rev. 276 (1944); Morse, The National War Labor Board Puts Labor Law Theory Into Action, 29 lowa L. Rev. 175 (1944).

The wartime labor experience is most often discounted on grounds of the extraordinary threat to national survival which then existed, and also on the basis of a no strike-no lock out pledge voluntarily made at the beginning of the war by both labor and management. But it is also significant that the wartime experience was comprehensive and of indefinite duration as distinguished from the ad hoc and temporary nature of the settlement process embraced by Public Law 88-108 and 90-54.

"State statutes now providing for compulsory arbitration of labor disputes apply solely to the state public utilities industries which are not covered by the National Labor Relations Act or Railway Labor Act. For an analysis of this legislation see Shenton, Compulsory Arbitration in the Public Service, I7 LAB. L.J. 138 (1966).

There is no case in which a state legislature has acted to resolve a labor impasse by the process of ad hoc compulsory arbitration. The state statutes aim at particular industries, simply outlawing work stoppages, rather than compelling resolutions of particular disputes, as did Public Laws 88-108 and 90-54.

${ }^{36}$ The work rules dispute leading to enactment of Publie Law 88-108 involved attempts by the carriers to eliminate certain jobs made superfluous by technological improvements in the industry.

In railroad parlance, "work rules" are the extensive set of rules composed of collective bargained agreements, judicial deeisions, and administrative rulings accumulated since the beginnings of governmental control. The work rules have been described as the "common law" of railroad labor relations. Brotherhood of R.R. Trainmen v. Akron \& B.B. R.R., 385 F.2d 581 (D.C. Cir. 1967), cert. denied, 390 U.S. 923 (1968); see Report of tHe Presidential Railroad Commission 3 (1962). The particular work rules in dispute in 1963 dealt with two aspects of railroad employment and operations policy: (1) the fireman issue-whether to continue the use of a fireman on diesel engines carrying freight; and (2) the crew consist issuewhether to reduce the size of train crews. The exact technical nature of these disputed issues is examined in Report of the Presidential Railroad Commission (1962). For an account of the history of the dispute and the speeial mediation and conciliation efforts which failed to achieve a voluntary resolution of the impasse see Brotherhood of Loco. Firemen v. Chicago, B. \& Q. Ry., 225 F. Supp. 11, 14-15 (D.D.C. 1964), affd, 331 F.2d 1020 (D.C. Cir.), cert. denied, 377 U.S. 918 (1964), and Brotherhood of R.R. Trainmen v. Akron \& B.B. R.R., 385 F.2d 581, 588-92 (D.C. Cir. 1967), cert. denied, 390 U.S. 923 (1968).

In contrast, the dispute resolved by Public Law 90-54 was a rather straightforward wage rate conflict. For the background of this dispute see S. Rep. No. 292, 90th Cong., 1st Sess. 5-10 (1967), and H.R. ReP. No. 353, 90th Cong., lst Sess. 5-6 (1967). 
compulsory arbitration to deal with emergency labor disputes on an ad hoc basis. Public Law 90-54, which followed in 1967, was a similar special statute requiring temporary third-party settlement of another railroad labor dispute. ${ }^{37}$ These statutes and the litigation surrounding them provide concrete experience by which to test the theoretical objections to compulsory arbitration.

\section{Constitutional Issues}

When a labor dispute threatens to interdict the services of an industry which is indispensable to the national health and safety, Congress unquestionably has power under the commerce clause to enact legislation compelling arbitration of the dispute. Prior to the passage of Public Law 88-108, the Supreme Court's decision in Wilson $v$. New ${ }^{38}$ was the most direct precedent upholding a statute through which Congress itself arbitrated a labor dispute in the railroad industry..$^{39}$ In Wilson, the Adamson Act, ${ }^{40}$ which reduced the

\footnotetext{
${ }^{37}$ Senator Morse, the primary draftsman of Public Law 90-54, has consistently rejected any characterization of the statute as a provision for compulsory arbitration; rather, he referred to the dispute settlement process as "mediation to finality." See Hearings on S.J. Res. 80 Before the Subcom. on Labor of the Senate Comm. on Commerce, 90th Cong., 1st Sess. 25 (1967); 113 Cong. REc.7783 (daily ed. June 7, 1967); Morse, The Role of Collective Bargaining in Our Society, 47 ORE. L. Rev. I (1967). Senator Morse's distinction is that under the provisions of 9054 the Special Board is bound to limit its award to the framework established in the collective bargaining. Most legislators, however, characterized $90-54$ as a compulsory arbitration act. See, e.g., 113 Cong. REC. 7209 (daily ed. June 14, 1967) (remarks of Representative Devine); 113 Cong. Rec. 7791 (daily ed. June 7, 1967) (remarks of Senator Prouty). At any rate, the scheme of dispute settlement set up by 90-54 clearly fits within the common conception of compulsory arbitration which emphasizes the mandatory nature of the process. See note 9 supra.

"243 U.S. 332 (1917).

${ }^{39}$ Although the Adamson Act, ch. 436, $§ 1,39$ Stat. 721 (1916), did not establish any separate arbitration panel, at least seven of the Justices in Wilson $v$. New were of the opinion that the Court was deciding the constitutionality of a compulsory arbitration law. 243 U.S. at 387, 389. The Solicitor General, in his argument to the Court, described the Adamson Act as a compulsory arbitration of the dispute wherein Congress itself had dictated directly the terms of the award rather than acting through a commission. Chief Justice White's opinion of the Court suggested no significant distinction between compulsory arbitration and direct legislation, stating that: "Congress had the power to adopt the act in question, whether it be viewed as a direct fixing of wages to meet the absence of a standard on that subject resulting from the dispute between the parties or as an exertion by Congress of the power which it undoubtedly possessed to provide by appropriate legislation for compulsory arbitration-a power which inevitably resulted from its authority to protect interstate commerce in dealing with a situation likc that befor it . . . "Id. at 359. The dissent of Mr. Justice McReynolds, along with the dissent of Justices Pitney and Van Devanter, accepted the compulsory arbitration terminology as applied to the legislation. Id. at 387. Mr. Justice McKenna's concurring opinion does not use the term "compulsory arbitration," but deals with the power of Congress to take any action under the circumstances. Id. at 360 .

4039 Stat. 721 (1916).
} 
work day in the railroad industry to eight hours without permitting an attendant wage reduction, was upheld against a challenge that it interfered with freedom of contract and deprived the railroads of their property without due process of law. The majority rationale justified direct Congressional resolution of the dispute on the ground that the railroads are a public utility industry in which a work stoppage would constitute emergency conditions. ${ }^{41}$ Since the emergency emanated solely from the threat of national rail service disruption and not from any extraneous source, Wilson $v$. New amounts to a holding that legislation providing for compulsory third-party settlement of such labor disputes is reasonable and thus not unconstitutional.

When Public Law 88-108 was enacted to resolve the railroad work rules dispute no serious doubt existed that the federal commerce power extended to regulation of the number of employees manning trains in interstate commerce. ${ }^{42}$ The constitutionality of Public Law 88-108 was challenged, however, on a different theory in Brotherhood of Locomotive Firemen v. Chicago, Burlington \& Quincy Railroad ${ }^{43}$ when the railroad unions sought to impeach the arbitration award. Confronted by the precedent of Wilson $v . N e w{ }^{44}$ the unions conceded Congressional power, ${ }^{45}$ and instead concentrated their attack on the allegedly inadequate and insufficient standards which Public Law 88108 prescribed for Arbitration Board 282 to follow in determining the award ${ }^{46}$ Relying on statutory language that required the Board to act with regard for "adequate and safe transportation service to the public" and for the "interests of the carrier and employees affected," $" 47$ a comparison was drawn to the language of the Emergency

11 243 U.S. at 332, 347, 352.

"2 See Brotherhood of Loco. Engineers v. Chicago, R.I. \& Pac. R.R., 382 U.S. 423, 425 (1966).

${ }^{43} 225$ F. Supp. 11 (D.D.C.), aff'd, 331 F.2d 1020 (D.C. Cir.), cert. denied, 377 U.S. 918 (1964).

" The Wilson precedent was relied upon by President Kennedy in proposing Public Law 88108, by the Congress in passing it, and by the courts in upholding its constitutionality. See Brotherhood of Loco. Firemen v. Chicago, B. \& Q. Ry., 225 F. Supp. 11 (D.D.C.), aff'd, 331 F.2d 1020 (D.C. Cir.), cert. denied, 377 U.S. 918 (1964); Message from the PresiDent of the United States Relative to the Railroad-Labor Dispute, H.R. Doc. No. 142, 88th Cong., Ist Sess. (1963); S. REP. No. 459, 88th Cong., 1st Sess. (1963).

45 225 F. Supp. at 22.

${ }^{46} I d$.

\77 Stat. 134. 
Price Control Act, ${ }^{48}$ the Fair Labor Standards Act, ${ }^{49}$ and other regulatory legislation which the Supreme Court had previously upheld against similar attack. The United States District Court for the District of Columbia consequently found that Public Law 88-108's standards were adequately specific to withstand constitutional attack..$^{50}$

Since Public Law 90-54 was enacted under the same circumstances as prior valid compulsory arbitration laws and contained materially similar provisions, this 1967 statute also seems clearly constitutional. Not only was it enacted in response to a threatened national rail strike, as were the statutes involved in Wilson v. New and the Burlington Road case, ${ }^{51}$ but also the standards it prescribed for deciding the dispute were at least as definite as those incorporated in Public Law 88-108..$^{52}$

By adhering to the courts' reasoning in the Wilson and Burlington Road cases, Congress could validly extend the compulsory arbitration process to settle labor disputes in other essential industries. The airlines and communications industries, for example, seem to fit the "public utility" rationale of Wilson $v$. New equally as well as does the railroad industry, and both are already subject to the same kind of extensive federal regulation now applicable to railroads. ${ }^{33} \mathrm{~A}$ nationwide strike in such industries would also meet any "emergency situation" limitation which could be read into either Wilson $v$. New or the Burlington Road case. Even if Congress were to extend compulsory arbitration to a labor dispute in an essential but relatively

"See Yakus v. United States, 321 U.S. 414, 423 (1944). In fixing prices under the Emergcncy Price Control Act of 1942, the Administrator was directed to establish fair and equitable prices and to conform to the standards prescribed by the Act.

${ }^{49}$ See Opp Cotton Mills, Inc. v. Administrator, 312 U.S. 126 (1941). The declared policy of the Fair Labor Standards Act was to raise minimum wages to forty cents an hour as rapidly as economically feasible without substantially curtailing employment.

${ }^{50} 225$ F. Supp. $11,23$.

st See S. ReP. No. 292, 90th Cong., 1st Sess. (1967); H.R. ReP. No. 353, 90th Cong., 1st Sess. (1967).

\$2 81 Stat. 123. Section 4 of Public Law 90-54 provided standards as follows: "The Special Board shall make its determination. . . , and shall incorporate the proposal of the Special Mediation Panel with such modifications, if any, as the Board finds to be necessary to (1) be in the public interest, (2) achieve a fair and equitable settlement within the limits of the collective bargaining and mediation efforts in this case, (3) protect the collective bargaining process, and (4) fulfill the purposes of the Railway Labor Act."

${ }^{33}$ See Railway Labor Act $\S \S 201-06,45$ U.S.C. $\S \S 181-86$ (1964); Federal Communications Act, 47 U.S.C. $\$ 151$ et seq. (1964); Federal Aviation Act of 1958, 49 U.S.C. $\S 1301$ et seq. (1964). 
unregulated private industry, such as coal or steel, there is very little, if any, likelihood that the legislation would be struck down on an "economic due process" rationale. In fact, given Congress' politically motivated aversion to compulsory arbitration, ${ }^{54}$ this mode of settlement is likely to be employed only in cases of such extreme danger to the public interest that any economic due process challenge would be palpably insubstantial. Thus, even with the broadest standards to guide the arbitrators' decision, no genuine question should arise concerning the constitutionality of a future ad hoc compulsory arbitration law.

\section{Defining the Scope of the Compulsory Arbitration Board's Authority}

While constitutional power to enact a compulsory arbitration statute presents few difficulties, the substantive provisions of the statute itself are not so easily handled. An ad hoc compulsory arbitration law must define two basic aspects of the arbitrators' jurisdiction: first, the particular issues that are submitted for the arbitrators' determination, and second, the scope of the arbitrators' discretionary power in making decisions. When a compulsory arbitration law is under consideration, the party opposing the arbitration will naturally urge incorporation of limits on the board's discretionary power as well as restriction of the specific issues submitted to the board. Indeed, by restricting the specific issues and incorporating decisional guidelines into the law itself, the legislature may significantly weaken the force of the objection that compulsory arbitration leaves the parties at the mercy of the economic prejudices and predilictions of the arbitrators..$^{55}$ Once a compulsory arbitration statute is enacted, an arbitrator's violation of his authority under the enabling legislation provides grounds for a direct action to impeach the award ${ }^{56}$ as well as a defense to any suit seeking its enforcement. ${ }^{57}$ ln any case, an award on issues not submitted to the arbitrator is totally void.

\footnotetext{
${ }^{54}$ See H.R. ReP. No. 353, 90th Cong., Ist Sess. 3 (1967); 113 CoNG. Rec. 7789 (daily ed. June 7, 1967) (remarks of Senator Javits); 113 CoNG. REc. 7797 (daily ed. June 7, 1967) (remarks of Senator Yarborough).

"See note 27 supra and accompanying text.

${ }^{36}$ See Brotherhood of Loco. Firemen v. Chicago, B \& Q. R.R., 225 F. Supp. 11, 17 (D.D.C.), aff d, 33I F.2d 1020 (D.C. Cir.), cert. denied, 377 U.S. 918 (1964).

"See ElKouri, supra note 9, at 26; C. UpdegrafF \& W. McCoy, ARBITRATION of LABOR Disputrs 125 (1946). See also Justin, Arbitration: Proving Your Case, 10 Lab. Arb. 955, 966-68 (1948).
} 
Public Laws 88-108 and 90-54 employed very different methods to define the authority of the panels empowered to decide their respective controversies. In the case of the work rules dispute, Public Law 88l08 identified the issues committed to arbitration by referring to the original union and carrier proposals that initiated the dispute, ${ }^{58}$ and left some additional contested issues to the further collective bargaining of the parties..$^{59}$ As a consequence, that statute provided no assurance that the entire dispute would be resolved. In contrast, the frame of reference for the Special Board established by Public Law 9054 was a mediation proposal which had previously been made by a mediation panel, but had been rejected by the parties. ${ }^{60}$ Since this mediation proposal embraced the only issues in the dispute, the Special Board was authorized to render a binding decision that would have the certain result of precluding a work stoppage. In practical effect, 88-108's method of defining the scope of the arbitrators' authority offered some encouragement for future voluntary collective bargaining, albeit at more risk to the public interest in uninterrupted rail service, while 90-54 provided absolute assurance that all issues would be resolved through governmental mandate. The flexibility of ad hoc legislation is thus demonstrated by its ability to promote different and conflicting policies, depending on Congress' assessment of which best serves the national interests under the circumstances.

The decisional standards incorporated into both Public Laws 88108 and $90-54$ were much too vague to guide the arbitrators in resolving the merits of the disputes or to provide adequate protection for the parties self-interest. ${ }^{61}$ Although the 88-108 arbitration board

\footnotetext{
${ }^{58}$ See 77 Stat. 133. Section 3 of Public Law 88-108 provided in part: "The arbitration board shall make a decision, pursuant to the procedures hereinafter set forth, as to what disposition shall be made of those portions of the carriers' notices of November 2, 1959, identified as 'Use of Firemen (Helpers) on Other Than Steam Power' and 'Consist of Road and Yard Crews' and that portion of the organizations' notices of September 7, 1960, identified as 'Minimum Safe Crew Consist' and implementing proposals pertaining thereto . . . ."

${ }^{59}$ See S. Rep. No. 459, 88th Cong., lst Sess. 3 (1963).

${ }^{60}$ See 81 Stat. 122. The Special Board was directed by Section 3 of the Act to "hold hearings on the proposal made by the Special Mediation Panel, in its report to the President of April 22, 1967 , in implementation of the collective bargaining contemplated in the recommendation of Emergency Board Number 169." These hearings were intended to determine the basic fairness of that proposal and its consistency with the public interest. The Special Board was then directed by section 4 to incorporate the Mediation Panel's proposal in its determination, with such changes as the hearings indicated were necessary for the decision to comport with the standards set forth in that section.

${ }^{61}$ See notes 47 and 52 supra.
} 
was restricted by a requirement that it incorporate in its award all matters on which the parties were in prior agreement, ${ }^{62}$ this restriction was without substance because the board itself was the ultimate judge of what matters had in fact been agreed upon. ${ }^{63}$ The Special Board established under 90-54 was more constrained, since its decisionmaking process started from the definite substantive terms of a prior mediation proposal, and deviated from those terms only as the Board deemed necessary to comply with the statutory standards. ${ }^{64}$ The final decision of the Special Board was also expressly required to be "within the limits of the collective bargaining and mediation efforts in this case." 65 The question of who determines the terms which in fact constitute the limits of collective bargaining, however, was left open. If the Special Board is the ultimate judge, then this provision is no more of a substantive limitation than existed under Public Law 88108. To adequately protect the parties' interests under ad hoc compulsory arbitration the statute should explicitly provide for a band of contract terms within which the arbitrators' decision must fall. This would be easiest in a straight wage dispute, where the statute could simply incorporate the terms of each party's last collective bargaining proposal. ${ }^{66}$ Otherwise, it is clear that unless there is an extensive measure of judicial review for compulsory arbitration awards, the arbitrators' power to effect the essential interest of the parties is limitless.

\section{Scope of Judicial Review of Compulsory Arbitration Awards}

The practical efficacy of procedural safeguards and decisional standards which are included in a compulsory arbitration statute depends on the scope of judicial review afforded the arbitration process. Such review was restricted in Public Law 88-108 by the

\footnotetext{
${ }^{62} \mathrm{See} 77$ Stat. 133. Section 3 of Public Law 88-108 provides in part: "The arbitration board shall incorporate in such decision any matters on which it finds the parties were in agreement, shall resolve the matters on which the parties were not in agreement, and shall, in making its award, give due consideration to those matters on which the parties were in tentative agreement. ..."

${ }^{63}$ See Brotherhood of Loco. Firemen v. Chicago, B. \& Q. R.R., 225 F. Supp. 11, 17 (D.D.C.), aff d, 331 F.2d 1020 (D.C. Cir.), cert. denied, 377 U.S. 918 (1964).

64 See Act of July 17, 1967, Pub. L. No. 90-54, § 4, 81 Stat. 123.

os Id.

${ }^{6}$ The disputed issues in the 1967 railroad dispute were well defined and the final bargaining proposal of each side could easily have been incorporated within Public Law 90-54. See H.R. REP. No. 353, 90th Cong., 1st Sess. 6-7 (1967).
} 
incorporation of section 9 of the Railway Labor Act, ${ }^{67}$ thereby limiting judicial review of Board 282 rulings to a determination of whether the award conformed to the provisions of the enabling act. Therefore, when the unions brought an action to impeach the award in Brotherhood of Locomotive Firemen v. Chicago, Burlington \& Quincy Railroad ${ }^{68}$ the district court disclaimed any power to review on the merits, holding that the Board's findings of fact were conclusive, even in the absence of substantial supporting evidence. ${ }^{69}$ Interpreting the statute as giving the Board wide discretionary powers to implement its award, the court also sustained the decision against union challenges that it was inconsistent with Public Law 88-108 in delegating arbitration of "crew consist" disputes to local "Adjustment Boards," "70 and in failing to incorporate prior unioncarrier agreements as required by section 3 of the Act."

Later cases more clearly demonstrated the Board's virtual autonomy. In Brotherhood of Railroad Trainmen v. Chicago, Milwaukee, St. Paul \& Pacific Railroad ${ }^{12}$ and in Brotherhood of Railroad Trainmen v. Certain Carriers, ${ }^{73}$ the Court of Appeals for the District of Columbia Circuit held that the substantive and procedural issues raised in proceedings before the Adjustment Boards were reviewable only by Board 282 , not by the judiciary. On the basis of the restricted measure of judicial review allowed by section 9 of the Railway Labor Act, another case held the question whether specific railroad practices conformed to the substantive mandates of the award to be within the jurisdiction of the arbitration board rather

${ }^{67}$ The Railway Labor Act allows impeachment of voluntary arbitration awards on the following grounds only:

"(a) That the award plainly does not conform to the substantive requirements laid down by this act for such awards, or that the proceedings were not substantially in conformity with this Act;

"(b) That the award does not conform, nor confine itself, to the stipulations of the agreement to arbitrate; or

"(c) That a member of the board of arbitration rendering the award was guilty of fraud or corruption; or that a party to the arbitration practiced fraud or corruption which fraud or corruption affected the result of the arbitration. . . ." 45 U.S.C. $\$ 159$ (1964).

${ }^{8} 225$ F. Supp. 11 (D.D.C.), affd, 331 F.2d 1020 (D.C. Cir.), cert. denied, 377 U.S. 918 (1964).

${ }^{69} \mathrm{Id}$. at 17. For a discussion of evidentiary requirements under Public Law 90-54 see note 88 infra.

${ }^{70}$ See note 36 supra for an explanation of the "crew consist" issue.

7225 F. Supp. at 17. There was no allegation that fraud tainted the award. Id. at 18.

7345 F.2d 985 (D.C. Cir. 1965).

${ }^{33} 349$ F.2d 207 (D.C. Cir. 1965). 
than the courts. ${ }^{74}$ The District of Columbia Circuit also upheld, ${ }^{75}$ on the same grounds, a Board ruling that exempted the Special Adjustment Boards from the procedural requirements of sections 7 and 8 of the Railway Labor Act, ${ }^{76}$ which Public Law 88-108 had expressly applied to arbitration decisions made by Board 282 itself. $^{.7}$ Therefore, by delegating some of its functions to local panels, Board 282 in effect rendered nugatory the procedural safeguards placed around its own action by Public Law 88-108. ${ }^{78}$ The Chicago Milwaukee ruling did require that Board 282 provide "meaningful review" of Adjustment Board proceedings to assure that the parties were accorded due process. ${ }^{79}$ However, since transcripts and written opinions, as a rule, did not accompany Adjustment Board decisions, ${ }^{80}$ the practical significance of the review provided by Board 282 seems questionable.

Judicial abstention from reviewing arbitrated questions may be justified on the ground that it minimizes litigation which might delay implementation of the award.$^{81}$ Arguably, such a limitation also tends to preserve the judgments of an expert panel on technical issues where, in theory, judges have less expertise. ${ }^{82}$ On the other hand, however, the

"Brotherhood of R.R. Trainmen v. Terminal R.R. Ass'n, 380 F.2d 584 (D.C. Cir.), cert. denied, 389 U.S. 940 (1967).

7s See Brotherhood of R.R. Trainmen v. Chicago, M., St. P. \& Pac. R.R., 383 F.2d 216 (D.C. Cir.), cert. denied, 389 U.S. 933 (1967); Brotherhood of R.R. Trainmen v. St. Louis S.W. Ry., 380 F.2d 603 (D.C. Cir.), cert. denied, 389 U.S. 927 (1967); Brotherhood of R.R. Trainmen v. Chicago, M., St. P. \& Pac. R.R., 380 F.2d 605 (D.C. Cir.), cert. denied, 389 U.S. 928 (1967).

${ }^{\prime 6}$ See 45 U.S.C. $\S \S 157-58$ (1964). To protect the carriers and the unions from abuse of power by an arbitration panel, these sections provide that both disputants are to receive a "full and fair hearing," with the opportunity to call witnesses and present evidence, and be represented by counsel if they so desire.

$n 77$ Stat. 133. Section 4 of Publie Law 88-108 provided in part: "To the extent not inconsistent with this joint resolution the arbitration shall be conducted pursuant to sections 7 and 8 of the Railway Labor Act, the board's award shall be made and filed as provided in said sections and shall be subject to section 9 of said Act."

${ }^{73}$ See Brotherhood of R.R. Trainmen v. Chicago, M., St. P. \& Pac. R.R., 383 F.2d 216, 218 (D.C. Cir.) (Wright, J., dissenting), cert. denied, 389 U.S. 933 (1967); Brotherhood of R.R. Trainmen v. St. Louis S.W. Ry., 380 F.2d 603, 604 (D.C. Cir.) (Wright, J., dissenting), cert. denied, 389 U.S. 927 (1967).

${ }^{79} 345$ F.2d 985, 987 (D.C. Cir. 1967).

${ }^{80}$ See Brotherhood of R.R. Trainmen v. Chicago, M., St. P. \& Pac. R.R., 383 F.2d 216, 218 (D.C. Cir.), cert. denied, 389 U.S. 933 (1967); Brotherhood of R.R. Trainmen v. St. Louis S. W. Ry., 380 F.2d 603, 604 (D.C. Cir.), cert. denied, 389 U.S. 927 (1967).

s' See Note, Judicial Review of Arbitration Awards on the Merits, 63 HARV. L. Rev. 681 (1950).

${ }^{82}$ In cases involving voluntary arbitration, the Supreme Court has severely limited judicial intervention, relying to a large extent in its rationale on the special expertise of arbitrators. See 
severely restricted impeachment procedures incorporated in Public Law 88-108 were designed for voluntary arbitration. ${ }^{83}$ In compulsory arbitration, there are other factors which ought to compel more extensive judicial review of the award. For instance, the parties did not assume voluntarily the risk of arbitrators' errors by consenting to the arbitration. ${ }^{84}$ Furthermore, while the issues involved in compulsory arbitration are likely to be more crucial to the parties' self-interest, ${ }^{85}$ the parties are denied the opportunity which exists under voluntary arbitration to protect themselves by the terms of the submission agreement. In view of these factors and the relative infrequency of recourse to compulsory settlement procedures, the parties should be accorded the protection of more extensive judicial review than was provided by Public Law 88-108.

Under Public Law 90-54, the United States District Court for the District of Columbia had exclusive jurisdiction of all suits concerning the determinations of the Special Board, but the scope of the judicial review of those determinations was not specified. ${ }^{86}$ As a result, section 10(e) of the Administrative Procedure Act $^{87}$ probably governs the scope of review for the Special Board's findings and conclusions. In general, this means that, unlike Board 282, the determinations of the Special Board could be set aside unless supported by substantial evidence. ${ }^{88}$ This standard provides some of the additional needed protection against the possible bias of arbitrators.

United Steelworkers v. Enterprise Wheel \& Car Corp., 363 U.S. 593, 596-97 (1960); United Steelworkers v. Warrior \& Gulf Navigation Co., 363 U.S. 574, 585 (1960); United Steelworkers v. American Mfg. Co., 363 U.S. 564, 568 (1960).

The District of Columbia Circuit, whieh had jurisdiction of all cases arising under Public Law 88-108, recognized the highly teehnieal nature of the problems involved in the work rules dispute and, apparently in an attempt to provide an adequately knowledgeable judicial forum, directed all the 88-108 cases to a single district judge. See Brotherhood of R.R. Trainmen v. Akron \& B.B. R.R., 385 F.2d 581, 605 n.53 (D.C. Cir. 1967), cert. denied, 390 U.S. 923 (1968).

${ }^{83}$ See note 67 supra.

"See Texoma Natural Gas Co. v. Oil Workers Int'l Union, 58 F. Supp. 132 (N.D. Tex. 1943), affd, 146 F.2d 62 (5th Cir. 1944), cert. denied, 324 U.S. 872 (1945); Note, Judiclal Review of Arbitration Awards on the Merits, 63 HARV, L. REV. 681, 682 (1950).

is See note 25 supra and accompanying text.

${ }^{25}$ Act of July 17, 1967, Pub. L. No. 90-54, § 5(c), 81 Stat. 124.

${ }^{31} 5$ U.S.C. $\$ 1009$ (e) (1964).

is In prescribing the seope of judicial review of actions by government agencies, the Federal Administrative Procedure Act provides the following grounds for holding unlawful and setting aside agency action: “(1) arbitrary, capricious, an abuse of discretion, or otherwise not in accordance with law; (2) contrary to constitutional right, power, privilege, or immunity; (3) in excess of statutory jurisdiction, authority, or limitations, or short of statutory right; (4) without 
The Effect of Temporary Compulsory Arbitration on the Duty to Bargain

The duty to bargain in good faith is imposed on all industries covered by either the National Labor Relations Act or the Railway Labor Act for the purpose of promoting the collective bargaining process ${ }^{89}$ However, when collective bargaining fails and compulsory arbitration is imposed, the question arises whether enactment of the compulsory arbitration statute revokes the duty to bargain over those issues submitted to arbitration. Although Public Law 88-108 was silent as to whether the statutory duty to seek a bargained agreement was suspended, the Act did provide that the disputed work rules arrived at through the compulsory arbitration process were subject to change by agreement of the parties. ${ }^{90}$ Furthermore, the Act's legislative history stressed a Congressional preference for a voluntarily bargained agreement. ${ }^{91}$ Thus, both the language and the history of the legislation seem to suggest that there should be no alteration of the parties' legal obligation to bargain.

The effect of Public Law 88-108 on the duty to bargain was first tested when the carriers refused to negotiate proposed changes in the work rules instituted by the compulsory arbitration award. When the unions proposed crew consist changes to take effect before the Award expired and sought a great increase in the employment of firemen effective the day after expiration, the carriers disclaimed any duty to bargain on these subjects. In a series of actions brought by the carriers

observance of procedure required by law; (5) unsupported by substantial evidence in any case subject to sections 1006 and 1007 of this title or otherwise reviewed on the record of an agency hearing provided by statute; or (6) unwarranted by the facts to the extent that the facts are subject to trial de novo by the reviewing court." 5 U.S.C. 1009(e) (1964).

Since Section 3 of Public Law 90-54 expressly directs the Special Board to hold hearings, the "substantial evidence" requirements of section 10(e) (5) should apply to Board actions. The provisions of sections 10 (e) (1) through $10(\mathrm{e})(4)$ provide basically the same scope of judicial review as governed decisions under Public Law 88-108. Sec note 67 supra.

${ }^{89}$ National Labor Relations Act $\S 8(5), 29$ U.S.C. § 158(a) (5) (1964); Labor Management Relations Act $\S 8$ (b) (3), 29 U.S.C. $\S 158$ (b) (3) (1964); Railway Labor Act $\S 2,45$ U.S.C. $\S \S$ 15I, (1964); see NLRB v. Insurance Agents' lnt'l Union, 361 U.S. 477 (1960); Virginian Ry. v. System Federation No. 40, Ry. Employees, 300 U.S. 515 (1937). See generally Cox, The Duty to Bargain in Good Faith, 71 HARv. L. Rev. 1401 (1958); Fleming, The Obligation to Bargain in Good Faith, 47 VA. L. Rev. 988 (1961).

${ }^{90} 77$ Stat. 133. Public Law 88-108 prohibited any change in the work rules from their status at the time the law was enacted "except hy agrecment, or pursuant to an arbitration award as hereinafter provided. . . ."Id.

"See Preamble to Act of August 28, 1963, Pub. L. No. 88-108, 77 Stat. 132; S. ReP. No. 459, 88th Cong., 1st Sess. 9 (1963); H.R. ReP. No. 713, 88th Cong., 1st Sess. 12-13 (1963). 
and the unions for declaratory judgments and injunctions against threatened strikes, a district court ruled that the union notices were "premature" and imposed no duty on the railroads to bargain during the life of the award. ${ }^{92}$ However, the Court of Appeals for the District of Columbia Circuit, in Brotherhood of Railroad Trainmen v. Akron \& Barberton Belt Railroad, ${ }^{93}$ reversed the district court's decision and held that while the award was in force, both parties had a duty to bargain over any proposals to change the work rules which would remain in effect after the award expired..$^{94}$

The conclusions reached by the district court and the court of appeals in these cases have stunningly different ramifications. On the one hand, the district court's decision meant that the commitment of an issue to compulsory arbitration excised it from the scope of collective bargaining. For example, where firemen were eliminated pursuant to the arbitration award, the district court held that proposals to replace the firemen were non-bargainable. ${ }^{95}$ The district court's conclusion that neither a carrier nor a union could proceed to set aside the results of the award ${ }^{96}$ implied that the work rules implemented under the award were not even permissible subjects of private bargaining and agreement. This result conflicted with the explicit Congressional preference for a solution reached through collective bargaining, ${ }^{97}$ and had the potential of freezing the parties permanently into those work rules instituted under the compulsory arbitration award.

On the other hand, the District of Columbia Circuit in Akron limited the implied abrogation of bargaining obligations to the period during which Award 282 was effective. ${ }^{98}$ Even while the award was in force, only those proposals to become effective before the award expired were held non-bargainable on grounds that they were

${ }^{92}$ See Bangor \& A. R.R. v. Brotherhood of Loco. Firemen \& Enginemen, 253 F. Supp. 682, 687 (D.D.C. 1966); Akron \& B.B. R.R. v. Order of Ry. Conductors, 253 F. Supp. 538, 539 (D.D.C. 1966); Akron \& B.B. R.R. v. Brotherhood of R.R. Trainmen, 250 F. Supp. 691, 697 (D.D.C. 1966).

${ }^{93} 385$ F.2d 581 (D.C. Cir. 1967), cert. denied, 390 U.S. 923 (1968).

it Id. at 594-99.

${ }^{95} 253$ F. Supp. 682, 687 (D.D.C. 1966).

\% The court's statement was that "[n]either a carrier, nor a union may institute proceedings, directly or indirectly, to set aside any provision of the Award, or the operations or activities that have taken place under it or the results that have been achieved." Id.

${ }^{97}$ See Preamble to Act of August 28, 1963, Pub. L. No. 88-108, 77 Stat. 132.

* 385 F.2d at 598-99. 
premature. ${ }^{99}$ For example, replacement of eliminated firemen after expiration of the award was held to be a legitimate proposal, subject to the good faith standards against which all proposals under the Railway Labor Act must be judged. ${ }^{100}$ However, in the case of notices aimed at procuring additional compensation for the individual firemen laid off under the award, the court of appeals agreed with the district court that the union had broached a non-bargainable issue. ${ }^{101}$ Reasoning from the premise that unions do not have the authority to bargain for their members in settlement of past grievances with the employer, ${ }^{102}$ the circuit court concluded that the unions were without power to concede any severance benefits accrued to dismissed firemen under Award 282. ${ }^{103}$ Since collective bargaining necessarily implies a "notion of mutuality," including at least the authority to both offer and concede on each side, the unions' lack of concessions power effectively precluded bargaining on this issue. ${ }^{104}$

In addition to express or implied revocation by the terms of the compulsory arbitration statute, the duty to bargain may also be eliminated when an arbitration award so drastically changes employment practices that a proposal to reinstate former practices is totally unreasonable. Although not involving compulsory arbitration, those cases which consider the content of collective bargaining proposals as evidence of bad faith support this analysis. ${ }^{105}$ For instance, in Vanderbilt Products, Inc. v. $N L R B^{106}$ the Court of Appeals for the Second Circuit held that an employer whose proposals were so one-sided that they could not conceivably have been accepted by the union, had violated his duty under the National

"Id. at 599.

${ }^{100}$ Id. at 603 . For a discussion of the "good faith" requirements of the duty to bargain, see American Airlines, Inc. v. Air Line Pilots Ass'n, Int'l, 169 F. Supp. 777, 793-98 (S.D.N.Y. 1958). Cf. NLRB v. United Clay Mines Corp., 219 F.2d 120, 125 (6th Cir. 1955); NLRB v. Reed \& Prince Mfg. Co., 205 F.2d 131, 134-35 (lst Cir.), cert. denied, 346 U.S. 887 (1953); Cox, supra note 89.

101385 F.2d at 600 .

${ }^{102}$ Id. at 603-04, citing Elgin, J. \& E. Ry. v. Burley, 325 U.S. 711 (1945).

${ }^{103} 385$ F.2d at 603 .

10. Id.

${ }^{105}$ See, e.g., Vanderbilt Prods., Inc. v. NLRB, 297 F.2d 833 (2d Cir. 1961); NLRB v. Reed \& Prince Mfg Co., 205 F.2d 131, 134-35 (lst Cir.), cert. denied, 346 U.S. 887 (1953).

${ }^{106} 297$ F.2d 833 (2d Cir. 1961). The employer in this case had conditioned further negotiations on union acceptance of a 5-year contract providing for a completely open shop, no union checkoff provision, and an absolute right on the part of the employer to discharge or lay off without restriction or seniority limitation. 
Labor Relations Act to bargain in good faith. From the decision in Akron, however, it is clear that while the content and timing of bargaining proposals may on occasion evidence bad faith, ${ }^{107}$ something more than a mere variance from the terms of the compulsory arbitration award is required to support a finding that the proposals are in fact non-bargainable. ${ }^{108}$

In summary, the judicial interpretations of Public Law 88-108 indicate that a temporary compulsory arbitration law may partially revoke the disputants' duty to bargain over certain issues by either temporarily removing their subject matter from the scope of mandatory collective bargaining, or by changing the factual context so that the good faith of the particular bargaining proposals is called into question. In the absence of a provision expressly revoking the duty to bargain, enactment of a temporary compulsory arbitration law provides no basis for inferring permanent changes in the substantive bargaining duties. During the life of the award, however, the settlement of other disputed issues may be promoted by recognizing a temporary respite in the mandatory bargaining over those points submitted to the arbitration board. ${ }^{109}$ Also, as a practical matter, the voluntary bargaining process which had failed to provide an acceptable compromise before compulsory arbitration is unlikely to be any more successful after the compulsory award has been instituted. Therefore, where compulsory arbitration is intended as a temporary solution, the law should be interpreted to withdraw the disputed issues only temporarily from mandatory bargaining.

Like Public Law 88-108, 90-54 also failed to state expressly its intended effect on the disputants' duty to bargain. ${ }^{110}$ However, since

${ }^{107} 385$ F.2d at 597.

${ }^{103}$ Id. at 598-603. However, the court noted that the union's proposals in fact called for less than a total reversion to the status quo ante Award 282; 6000 fewer firemen would have been required than under the former existing agreement. Id. at $603 \mathrm{n.48}$.

${ }^{109}$ See 385 F.2d at 598.

110 There is evidence in the legislative history of Public Law 90-54 to the effect that the parties have a duty to continue to bargain throughout the two-year period covered by any award under the statute. See H.R. REP. No. 353, 90th Cong., 1st Sess. (1967); 113 CoNg REC. 7204 (daily ed. June 14, 1967) (remarks of Representative Friedel). Representative Jarman's report from the House Committee on Interstate and Foreign Commerce expressly disapproved the construction of Public Law 88-108 that revoked the duty to bargain and stated the Committee's intent that the legal obligation to bargain continue unabated. H.R. REP. No. 353, 90th Cong., 1st Sess. 4 (1967). To support its conclusion that the continued duty to bargain is made "explicit" by 90-54, the committee report relies on the language in Seetion 5(a) stating tbat "the determination of the Special Board shall take effect and shall continue in effect until the parties reach 
90-54's Special Board served a mediation function prior to its final determination of the dispute, ${ }^{\mathrm{II}}$ and since mediation presupposes good faith bargaining by the parties, Congress evidently intended that the duty to bargain continue at least until the time limit set for an agreement by the parties had expired. But with respect to the period while the dictated settlement terms are in effect, Public Law 90-54 is mute on the issue of whether the parties have a duty to bargain. ${ }^{112}$ Section 5 of the statute, which provides that the determination of the Special Board has "the same effect as though arrived at by agreement of the parties under the Railway Labor Act," does not decide the question because the duration of the hypothetical "agreement" is not specified. ${ }^{113}$ A court could, however, reasonably infer a duration of two years from the fact that the statute provides for this maximum effective period in the absence of agreement by the parties. ${ }^{14}$ This construction would mean that Public Law 90-54 has exactly the same effect on the duty to bargain as did Public Law 88-108: There would be no duty to bargain over proposed changes in terms and conditions of employment instituted by the award unless the changes were proposed for implementation only after expiration of the award. ${ }^{115}$

\section{Impact on State Laws}

When Congress enacts a statute regulating the terms of employment in an industry, such as railroads, which is also regulated extensively by the states, a conflict may arise between the employment conditions instituted under federal law and the requirements of state law. Such a conflict seems to present a classic case for operation of the

agreement" (emphasis supplied in committee report). Id. This is certainly not the obvious meaning of this language, but if the committee's interpretation is embraced, unlike Public Law 88-108, the result would require mandatory bargaining during the entire period of the award. Where such important legal obligations are involved, if the majority of Congress did intend this result, it would seem that the statute would have been drafted more clearly.

'" See Act of July 17, 1967, Pub. L. No. 90-54, § 2, 81 Stat. 123; Hearings on S.J. Res. 81 Before the Subcomm. on Labor of the Senate Comm. on Labor and Public Welfare, 90th Cong., 1st Sess. 25 (1967); 113 CoNG. REC. 7783-84 (daily ed. June 7, 1967) (remarks of Senator Morse).

112 But see note 110 supra.

${ }^{113}$ Act of July 17, 1967, Pub. L. No. 90-54, \$ 5(a), 81 Stat. 123.

"The first sentence of Section 5(a) of 90-54 provides: "If agreement has not been reached by the parties upon the expiration of the period speeified in section 6 , the determination of the Special Board shall take effect and shall continue in effect until the parties reach agrecment or, if agreement is not reached, until such time, not to exceed two years from January 1, 1967, as the Board shall determine to be appropriate." 81 Stat. 123.

"see notes 98-100 supra and accompanying text. 
doctrine of federal preemption, under which the state law, possibly a safety regulation enacted in exercise of the state's police powers, would be rendered invalid. ${ }^{116}$ Public Law 88-108 raised this problem because the ensuing arbitration award provided for the elimination of firemen while the laws of some states continued to require a fireman as a part of a specified minimum crew for trains operating within the state. ${ }^{117}$ Six states subsequently repealed their full crew laws, ${ }^{118}$ and the Nevada Supreme Court construed the Nevada statute as not applying to diesel-powered locomotives. ${ }^{119}$ However, other states retained their full crew laws, which were predictably challenged by the carriers. In Chicago, Rock Island \& Pacific Railroad v. Hardin, ${ }^{120}$ the railroads argued that two Arkansas full crew statutes ${ }^{121}$ had been superseded by Public Law 88-108 and Award 282. The carriers further attacked the Arkansas laws as arbitrary and capricious, as discriminating against interstate commerce, and as imposing an unreasonable burden on interstate commerce. ${ }^{122}$ After a three-judge district court struck down the Arkansas statutes solely on the preemption argument, a Texas court relied on their holding in the case of Texas v. Southern Pacific $\mathrm{Co}^{123}$ to invalidate similar laws in that state. On direct appeal, however, the Supreme Court reversed the district court in the Chicago Rock Island case, emphasizing the absence of express Congressional intent to supersede state regulation in this area. ${ }^{124}$ The majority of the Court interpreted the intent of Congress in enacting Public Law 88-

\footnotetext{
${ }^{116}$ See, e.g., Florida Lime and Avocado Growers, Inc v. Paul, 373 U.S. 132 (1963); Cloverleaf Butter Co. v. Patterson, 315 U.S. I48, I54 (1942); Atlantic Coast Line R.R. v. Georgia, 234 U.S. 280, 292 (1914).

${ }^{117}$ The states were Arizona, Arkansas, California, Indiana, Mississippi, Nebraska, Nevada, New York, North Dakota, Ohio, Oregon, Texas, Wasbington, Wisconsin. See Hearings on Railroad Work Rules Dispute Before the Senate Comm. on Commerce, 89th Cong., Ist Sess., ser. 89-45, at 961 (1966).

its Mississippi, Oregon, and Nebraska repealed their full crew statutes tbrough legislative action, while initiative measures submitted to the voters in Arizona, California and North Dakota eliminated similar laws in those states.

${ }^{119}$ Southern Pac. Co. v. Dickerson, 80 Nev. 572, 397 P.2d 187 (1964).

120239 F. Supp. I (D. Ark. 1965), rev'd, 382 U.S. 423 (1966).

121 See ARK. STAT. ANN. $\$ \S 73-720$ to 73-722, 73-726 to 73-729 (1957). The provisions of the Arkansas statutes were characteristic of the laws of the other 12 states with full crew regulations. Generally, the laws provide that no freight train sball be equipped with a crew consisting of less than an engineer, a fireman, a conductor and a specified number of brakemen. See, e.g., ARK. STAT. ANN. § 73-720 (1957); IND. STAT. ANN. \$§ 55-1328 to 55-1332 (Burns ed. 1951).

122239 F. Supp at 4.

${ }^{123} 392$ S.W.2d 497 (Tex. Civ. App. 1965).

124382 U.S. at 435.
} 
108 as meaning to effect as little change as possible in the basic structure of laws governing the railroad industry while preventing the disaster of a general rail strike. ${ }^{125}$ Where compulsory arbitration is enacted as a temporary stop-gap measure, as was the case with Public Laws 88-108 and 90-54, the continued merit of individual state regulatory laws is unlikely to be carefully considered. ${ }^{126}$ Without such examination, Congress probably did not intend to preempt such state statutes, even though superficially they appear inconsistent with the terms of the arbitration award. With this reasoning, the Supreme Court's holding in Chicago Rock Island established a sound precedent for measuring the preemption effects of any subsequent ad hoc compulsory arbitration legislation.

The decision of the three-judge district court on remand of the Chicago Rock Island case ${ }^{127}$ indicates that the compulsory arbitration award may still have contributed indirectly to invalidating the state full crew laws. Arguably, by providing for extensive changes in the manning work rules in other states, Public Law 88-108 so changed the overall context within which the state statutes operate, that they now unreasonably burden interstate commerce. Partially on this reasoning and on the basis of safety records of railroads operating in other states, the Arkansas district court was convinced that firemen are in fact superfluous. ${ }^{128}$ Accordingly, the three-judge court found the full crew laws to be "unreasonable and oppressive ... and . . . [an unconstitutional] burden [on] interstate commerce." 129

\section{Work Rules in Effect at Expiration of $A$ ward 282}

One of the most disturbing features of Public Law 88-108 was the uncertainty as to whether the imposed work rules would remain in

${ }^{125}$ Id.

${ }^{126}$ Cf. Maurer v. Hamilton, 309 U.S. 598 (1940). "As a matter of statutory construction congressional intention to displace local laws in the exercise of its commerce power is not, in general, to be inferred unless clearly indicated by those considerations whieh are persuasive of the statutory purpose." Id. at 614.

${ }^{127}$ Chieago, R.I. \& Pac. R.R. v. Hardin, 274 F. Supp. 294 (D. Ark. 1967), appeal docketed, No. 18, Sup. Ct., Dec. 29, 1967.

${ }^{123}$ Id. at 303. A contrary result, upholding the constitutionality of almost identical full crew statutes against similar attacks, was reached by the Supreme Court of Indiana. See Public Service Comm'n v. New York Cent. R.R., Ind. , 216 N.E.2d 716, cert. denied, 385 U.S. 843 (1966). The New York Supreme Court, Appellate Division, has also recently declared that state's full crew statute constitutional, but the holding was based on procedural grounds and did not reflect any opinion on the merits. See New York Cent. R.R. v. Lefkowitz, 27 App. Div. 2d 735,282 N.Y.S.2d 68 (1967).

129274 F. Supp. at 303. 
effect after the expiration of Award 282. While the award was in effect, severance benefits of some $\$ 36,000,000$ were paid to dismissed firemen, and the carriers committed themselves to technicaloperations changes which made a return to the status quo economically unfeasible. ${ }^{130}$ Thus, the carriers took the position that the reduction of train and engine crews remained in effect. The Brotherhoods, on the other hand, contended that when the award expired, the work rules requiring a fireman on all runs and the old level of crew consist were reinstated. In Brotherhood of Railroad Trainmen v. Akron \& Barberton Belt Railroad ${ }^{131}$ the District of Columbia Circuit affirmed the district court rulings on this issue, holding that the industry had reached a "new plateau" of work rules under the award and that subsequent changes in the work rules were governed by the Railway Labor Act which requires alterations in existing employment terms to be made only after bargaining. ${ }^{132}$ The court's holding was based on an assessment of the practical changes initiated by Award 282, as well as an interpretation of the legal requirements of the Railway Labor Act.

The Akron case demonstrated that the effect of ad hoc compulsory arbitration on the continuing terms of employment does not end with the expiration of thc award. In general, a compulsory arbitration decision is treated the same as a voluntary decision, or a direct agreement between the disputants. Thus, negotiations for a new labor contract are begun on the basis of the currently existing terms of employment, not on the basis of the hypothetical situation that would have existed in the absence of compulsory arbitration. As a further progressive influence, the $A$ kron decision promotes a policy of allowing an industry subject to compulsory arbitration to undertake technological and operations innovation in reliance on the new terms of employment instituted under the award.

\section{Enforcement of Federal Compulsory Arbitration Statutes}

The feasibility of compulsory arbitration as a method of resolving national emergency labor disputes ultimately depends upon the willingness of the disputants to acquiesce in the award, even if unfavorable, or, in the alternative, upon whether their compliance can

\footnotetext{
${ }^{130}$ See Brotherhood of R.R. Trainmen v. Akron \& B.B. R.R., 385 F.2d 581, $592-94$ (D.C. Cir. 1967), cert. denied, 390 U.S. 923 (1968).

${ }^{131}$ Id.

${ }^{132}$ Id. at $592-94$.
} 
be forced by legal pressure. The failure of state no-strike statutes, such as New York's defunct Condon-Wadlin Act, ${ }^{133}$ lends some support to the argument that settlement processes like compulsory arbitration, which depend upon outlawing strikes to prevent work stoppages, are unenforceable. ${ }^{134}$ However, in the light of the experiences under Public Law 88-108, this argument has much less force with respect to federal statutes which have behind them the prestige of the national government and the enforcement powers of the federal courts.

The efficacy of the federal courts in enforcing compulsory arbitration laws depends primarily on their jurisdiction to issue injunctions and restraining orders. The strict policy of judicial nonintervention in labor disputes, effectuated by the Norris-LaGuardia Act, ${ }^{135}$ exists today in a compromised form. ${ }^{136}$ This anti-injunction statute continues as a forceful expression of the view that the courts are unprepared to handle the economic issues involved in labor disputes, and consequently should not have access to a strike-breaking weapon so susceptible of abuse as the labor injunction. Since neither Public Law 88-108 nor 90-54 expressly prescribed their effect on the Norris-LaGuardia Act, the question arises whether section 4 of that statute $^{137}$ deprives the federal courts of injunctive jurisdiction to enforce a federal ad hoc compulsory arbitration law enacted to settle a dispute over the terms of a new labor contract. Public Law 88-108 seemed to settle the issue by explicitly empowering "any court of the United States having jurisdiction of the parties" to issue the necessary enforcement orders upon suit by the Attorney General. ${ }^{138}$ However, this provision expired 180 days after enactment, ${ }^{139}$ and thus could not

${ }^{133}$ N.Y. Sess. Law, Ch. 790, § 108 (Condon-Wadlin Act) (repealed 1967). For discussion of the failure of Condon-Wadlin and its repeal and replacement by the Public Employees' Fair Employment Act, N.Y. CIv. SeRv. LAw §§ 200-10 (McKinney Supp. 1967), see Wolk, Public Employee Strikes-A Survey of the Condon-Wadlin Acts, 13 N.Y.L.F. 69 (1967).

${ }^{134}$ See note 32 and accompanying text.

1329 U.S.C. § 101-15 (1964).

${ }^{136}$ See Loeb, Accommodation of the Norris-LaGuardia Act to Other Federal Statutes, 11 LAB. L.J. 473 (1960).

137 The relevant part of section 4 of Norris-LaGuardia states: "No court of the United States shall have jurisdiction to issue any restraining order or temporary or permanent injunction in any case involving or growing out of any labor dispute to prohibit any person or persons participating or interested in such dispute (as these terms are herein defined) from doing, whether singly or in concert, any of the following acts: (a) Ceasing or refusing to perform any work or to remain in any relation of employment; . . ." 29 U.S.C. at $\S 104$.

13877 Stat. 134.

i39 Id. 
serve as a basis for injunctive jurisdiction to enforce an award which was binding for two years. Nevertheless, there are cases tracing the interrelationships of Norris-LaGuardia and the Railway Labor Act that would bear on this issue under any future legislation similar to Public Laws 88-108 and 90-54.

In Brotherhood of Railroad Trainmen v. Chicago River \& Indiana Railroad, ${ }^{140}$ the Supreme Court confronted an imminent strike which threatened to subvert the Railway Labor Act's provision for compulsory arbitration of disputes growing out of grievances or interpretation of existing agreements, known in the industry as "minor disputes." ${ }^{41}$ In upholding a permanent injunction against the strike, the Court reasoned that since compulsory arbitration provides a reasonable alternative to the strike weapon, the labor injunction cannot have the pernicious effects on labor's interest that prompted the enactment of Norris-La Guardia. ${ }^{142}$ Secondly, the Court developed the rationale of accommodating the earlier more general language of the Norris-LaGuardia Act to the more specific commands of the 1934 amendments to the Railway Labor Act which included the compulsory grievance arbitration provision. ${ }^{143}$ The main points of the Chicago River rationale upholding a permanent anti-strike injunction would seem to apply with equal cogency to contract negotiations, referred to as "major disputes," 144 where legislation such as Public Law 88-108 is in force. The crucial fact behind the Chicago River exception to Norris-LaGuardia was that a strike would have frustrated the explicit purpose behind section 3 of the Railway Labor Act. Clearly, the same threatened subversion of a "pattern of labor legislation" that the Court found in Chicago River ${ }^{145}$ would be present

140353 U.S. 30 (1957).

"' See Railway Labor Act \$ 3, 45 U.S.C. § 153 (1964). In Elgin, J. \& E.R.R. v. Burley, 325 U.S. 711 (1945), the Supreme Court distinguished "major disputes" from "minor disputes" as follows: "[The major dispute] relates to disputes over the formation of collective agreements or efforts to secure them. They arise where there is no such agreement or wherc it is sought to change the terms of one, and therefore the issue is not whether an existing agreement controls the controversy. They look to the acquisition of rights for the futurc, not to assertion of rights claimed to have vested in the past.

[The minor dispute], however, contemplates the existence of a collective agreement already concluded or, at any rate, a situation in which no effort is made to bring about a formal change in terms or to create a new one." Id. at 723.

142353 U.S. 30,41 (1957).

${ }^{103}$ Id. at 41-2. See generally Note, Accommodation of the Norris-LaGuardia Act to Other Federal Statutes, 72 HARv. L. REv. 354 (1958).

14 See note 141 supra for an explanation of the "major dispute-minor dispute" distinction.

iss 353 U.S. at 42. 
where a work stoppage in violation of Public Law 88-108 or 90-54 was imminent. For purposes of determining the effect of NorrisLaGuardia, there is thus no rational distinction between imposition of compulsory arbitration in major as well as minor disputes. ${ }^{146}$ Therefore, Chicago River should be controlling, and, even without express statutory authorization, the federal courts should be held to have jurisdiction to issue injunctions prohibiting strikes in violation of any ad hoc compulsory arbitration statute.

This conclusion is supported by Brotherhood of Locomotive Firemen v. Bangor \& Aroostock Railroad, ${ }^{147}$ a recent major-disputes case which accepted as its basic premise that "Norris-LaGuardia will not apply to preclude injunctive relief in cases in which the acts to be enjoined are in violation of the Railway Labor Act." ${ }^{148}$ In Bangor, the unions challenged the legality of restraining orders issued by the district court to enjoin a strike on account of the unions' failure to comply with the necessary bargaining procedures prescribed by the Railway Labor Act. The District of Columbia Circuit held that the federal courts had the appendant power, based on the public interest in avoiding a major rail strike, to preserve the status quo while determining whether a strike would contravene the mandate of the Railway Labor Act. The importance of Bangor for the law of contract negotiation arbitration is twofold. First, it stands as a "major disputes" case supporting the conclusion which logically follows from Chicago River that in spite of Norris-LaGuardia, the federal courts could enforce arbitration awards by injunctive relief. Second, Bangor's formulation of the appendant jurisdiction rationale affirms the judicial "power to order maintenance of the status quo" by precluding litigants from acting on the expectation that the court's order will be overruled, ${ }^{150}$

The District of Columbia Circuit confronted another important aspect of the problem of judicial enforcement in this area in a supplemental opinion to Brotherhood of Railroad Trainmen v. Akron

\footnotetext{
${ }^{146}$ In Order of Railroad Telegraphers v. Chicago \& N.W.R.R., 362 U.S. 330 (1960), the Supreme Court did apply section 4 of the Norris-LaGuardia Act to deny the federal courts injunctive power in a case involving a "major dispute." The case is clearly distinguishable, however, from Chicago River and any case involving a strike in violation of a compulsory arbitration plan, because the strike involved in Telegraphers violated no relevant statute.

i47 380 F.2d 570 (D.C. Cir. 1967), cert. denied, 390 U.S: 923 (1968).

14t Id. at 583 .

${ }^{149}$ Id. at 583-84.

${ }^{150} \mathrm{Id}$. at 583 .
} 
\& Barberton Belt Railroad. ${ }^{151}$ The union contended that section 8 of the Norris-LaGuardia Act ${ }^{152}$ precluded the railroads from obtaining a restraining order or injunction because the railroads had themselves breached their duties under the Railway Labor Act. Being consistent with its prior holdings, the tribunal affirmed the district court's jurisdiction to enjoin the strikes, ${ }^{153}$ but held that the lower court erred in deciding that the carriers had not violated the Railway Labor Act. ${ }^{154}$ The Akron court reasoned that since the railroads had acted illegally by refusing to bargain on some proper union contract proposals, section 8 of the Norris-LaGuardia Act applied with the result that the district court's injunction was erroneously granted. ${ }^{155}$ Nevertheless, because the "clean hands" provision of section 8 did not affect the jurisdiction of the court, the unions had a duty to obey the court orders even though invalid. The ruling in Akron is consistent with an earlier Supreme Court decision holding that section 8 barred the issuance of an injunction even against violence during a strike because the carrier had refused arbitration as a method of settling the dispute. ${ }^{156} \mathrm{Also}$, in later cases involving both major ${ }^{157}$ and minor ${ }^{158}$ disputes, anti-strike injunctions were denied to carriers where they had failed to comply with Railway Labor Act procedures. ${ }^{159}$

Under legislation such as Public Law 88-108 and 90-54, where the disputants' bargaining obligations are so uncertain, these precedents requiring strict application of the "clean hands" doctrine could raise serious legal problems. If the carriers are denied injunctions by section 8 of the Norris-LaGuardia Act, a question arises as to who would

131385 F.2d 581, 607 (D.C. Cir. 1967), cert. denied, 390 U.S. 923 (1968).

13229 U.S.C. $\S 108$ (1964). Section 8 of the Norris-LaGuardia Act states: "No restraining order or injunctive relief shall be granted to any complainant who has failed to comply with any obligation imposed by law which is involved in the labor dispute in question, or who has failed to make every reasonable effort to settle such dispute either by negotiation or with the aid of any available governmental machinery of mediation or voluntary arbitration." Id.

133385 F.2d at 613; see Brotherhood of Loco. Firemen v. Bangor \& A.R.R., 380 F.2d 570 (D.C. Cir. 1967), cert. denied, 390 U.S. 923 (1968).

ist 385 F.2d at 613; see Brotherhood of R.R. Trainmen v. Akron \& B.B. R.R., 385 F.2d 581, 599 (D.C. Cir. 1967), cert. denied, 390 U.S. 923 (1968).

iss Id. at 613-14.

${ }^{136} \mathrm{See}$ Brotherhood of R.R. Trainmen v. Toledo, Pac. \& W.R.R., 321 U.S. 50 (1944).

157 Butte Atl. \& Pac. Ry. v. Brotherhood of Loco. Firemen, 268 F.2d 54 (9th Cir.), cert. denied, 361 U.S. 864 (1959) (alternative holding).

iss Rutland Ry. v. Brotherhood of Loco. Engineers, 307 F.2d 21 (2d Cir. 1962), cert. denied, 372 U.S. 954 (1963).

${ }^{139}$ See also Chicago, R.1. \& Pac. R.R. v. Switchmen's Union, 292 F.2d 61 (2d Cir. 1961), cert. denied, 370 U.S. 936 (1962). 
have standing to apply to the court for an anti-strike injunction to protect the public against an incapacitating strike. Perhaps on some extension of the accommodation rationale, ${ }^{160}$ a court could enjoin the strike in spite of section $8 .{ }^{161}$ Of course, the best solution to this potential dilemma would be to provide explicitly for jurisdiction in the federal courts to issue the necessary orders upon suit by the Attorney General. Section (7)b of Public Law 88-108 embodied adequate language for this purpose. ${ }^{162}$ If the provision had been simply extended to remain in force for the duration of the award, the public interest in maintenance of essential transportation services would have been better protected:

\section{Conclusion}

By preventing the paralysis of a national rail strike, both Public Laws 88-108 and 90-54 accomplished the purpose of their enactment. In this respect, the ad hoc compulsory arbitration approach to national emergency disputes has served the national interest well. The often cited objection that such statutes are unenforceable must be significantly discounted in view of this experience. But the plethora of controversies and litigation that plagued Public Law 88-108 may support to some extent the argument that compulsory arbitration exacerbates rather than resolves labor disputes.

Most of the areas of weakness and uncertainty in Public Laws 88108 and 90-54 which this comment has examined could be eliminated in future legislation by more explicit and precise drafting. To summarize, the analysis of these statutes suggests that a temporary compulsory arbitration law should expressly provide for the following:

(1) In granting an injunction or relief under the compulsory arbitration statute, the jurisdiction of the federal courts shall not be limited by the Act entitled "An Act to amend the Judicial Code, to define and limit the jurisdietion of courts sitting in equity, and for other purposes," approved March 23, 1932 (29 U.S.C. §§ 101-115);

\footnotetext{
${ }^{160}$ See note 143 supra and accompanying text.

${ }^{161}$ See Brotherhood of R.R. Trainmen v. Chicago R. \& Ind. R.R., 353 U.S. 30 (I957); Brotherhood of R.R. Trainmen v. Akron \& B.B. R.R., 385 F.2d 581, 614 (D.C. Cir. 1967), cert. denied, 390 U.S. 923 (I968); Loeb, supra note 136.

16277 Stat. I34.
} 
(2) The Attorney General of the United States is empowered to apply to the courts for an injunction to prevent a strike or lockout at any time while the compulsory arbitration statute is in effect;

(3) The scope of judicial review of determinations by any special agency established under the compulsory arbitration statute shall be the same as that prescribed by section 10(e) of the "Federal Administrative Procedure Act" (5 U.S.C. §§ 1001-1011);

(4) The duty to bargain over terms and conditions of employment by the parties subject to the compulsory arbitration statute, whether such terms of employment are proposed to take effect before or after the expiration of the statute, shall not be [shall be] suspended during the effective period of the statute;

(5) The terms and conditions of employment existing upon the expiration of the compulsory arbitration statute shall continue in effect until changed in accordance with the labor laws applicable to the parties and the industry in question.

Although Public Laws 88-108 and 90-54 are usually viewed at best as unfortunate precedent, ${ }^{163}$ this ad hoc use of compulsory arbitration may provide an effective alternative to economic warfare that would have disastrous effects upon our interdependent national economy. In fact, such ad hoc solutions may be the only alternative to a general law compelling settlement of labor disputes in all essential industries, a law which might wholly destroy the fabric of collective bargaining. So long as Congress can be relied upon to act in similar national emergencies with swiftness and efficacy, such a permanent law is unnecessary, and probably undesirable.

${ }^{163}$ See Comment, The Railway Work Rules Dispute-A Precedent for Compulsory Arbitration, 14 DePaul L. Rev. 115 (1964). 